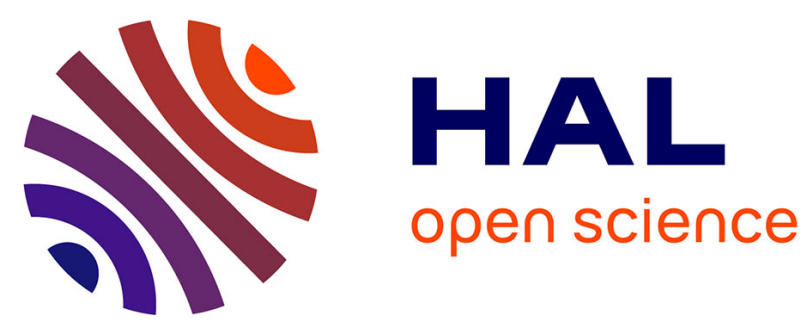

\title{
STRUCTURE AND CRYSTALLIZATION OF FLUOROZIRCONATE GLASSES. STUDY BY THE FLUORESCENCE OF Pr3+ IONS
}

\author{
M. Ferrari, J. Rousset, A. Boukenter, A. Boyrivent, E. Duval, A. Monteil
}

\section{- To cite this version:}

M. Ferrari, J. Rousset, A. Boukenter, A. Boyrivent, E. Duval, et al.. STRUCTURE AND CRYSTALLIZATION OF FLUOROZIRCONATE GLASSES. STUDY BY THE FLUORESCENCE OF Pr3+ IONS. Journal de Physique Colloques, 1987, 48 (C7), pp.C7-463-C7-465. 10.1051/jphyscol:19877110 . jpa-00226927

\section{HAL Id: jpa-00226927 https://hal.science/jpa-00226927}

Submitted on 1 Jan 1987

HAL is a multi-disciplinary open access archive for the deposit and dissemination of scientific research documents, whether they are published or not. The documents may come from teaching and research institutions in France or abroad, or from public or private research centers.
L'archive ouverte pluridisciplinaire HAL, est destinée au dépôt et à la diffusion de documents scientifiques de niveau recherche, publiés ou non, émanant des établissements d'enseignement et de recherche français ou étrangers, des laboratoires publics ou privés. 


\title{
STRUCTURE AND CRYSTALLIZATION OF FLUOROZIRCONATE GLASSES. STUDY BY THE FLUORESCENCE OF $\mathrm{Pr}^{3}$ * IONS
}

\author{
M. FERRARI ( 1 ), J.L. ROUSSET, A. BOUKENTER, A. BOYRIVENT, \\ E. DUVAL and A. MONTEIL \\ Laboratoire de Physico-Chimie des Matériaux Luminescents, \\ CNRS UA-442 et Université Claude Bernard, Lyon I, \\ 43. Bd du 11 novembre 1918, F-69622 villeurbanne Cedex, \\ France
}

\section{ABSTRACT}

The ${ }^{1} \mathrm{D}_{2} \rightarrow{ }^{3} \mathrm{H}_{4}$ fluorescence in fluorozirconate glasses has been studied in nonheated and heated samples. From spectra ani decays, several informations were obtained. Two types of crystals grow in this glass. By thermal treatment at $T_{\mathrm{g}}$ a demixtion of the constituants appears. It was impossible to obtain transparent vitroceramics.

\section{INTRODUCTION}

Several different fluorozirconate glasses provided by the Laboratoire de Chimie Minérale $D$, University of Rennes, have been studied. We present here the results obtained with $\mathrm{ZBA}\left(58.5 \%, \mathrm{ZrF}_{4}, 34.5 \% \mathrm{BaF}_{2}, 7 \% \mathrm{AlF}_{3}\right)$ doped with $\mathrm{Pr}^{3+}$ ions $\left(\mathrm{PrF}_{3}\right.$ is substituted for $\mathrm{AlF}_{3}$ ).

Several studies of $\mathrm{Pr}^{\text {ot }}$ fluorescence in fluorozirconate glasses have been published ${ }^{1,2}$. The study of ${ }^{1} \mathrm{D}_{2} \rightarrow{ }^{3} \mathrm{H}_{4}$ fluorescence is described in this communication.

\section{EXPERIMENTAL RESULTS}

The ${ }^{1} \mathrm{D}_{2} \rightarrow{ }^{3} \mathrm{H}_{4}$ fluorescence is detected after excitation at $5827 \AA$ in the highest sublevels of the split ${ }^{1} \mathrm{D}_{2}$ level of $\mathrm{Pr}^{3+}$ ions. Due to the large inhomogeneous broadening the ${ }^{2} \mathrm{D}_{2} \rightarrow{ }^{3} \mathrm{H}_{4}$ is very wide. In figure 1 , the ${ }^{1} \mathrm{D}_{2} \rightarrow{ }^{3} \mathrm{H}_{4}$ emission in non heated glass and heated $24 \mathrm{~h}$ at $330^{\circ} \mathrm{C}$ are compared. The heated sample was crystallized and translucent. From this crystallized sample appeared four lines. The characteristics of the two higher lines (shape and decay) were identical, and it is assumed that

\footnotetext{
(1) Sponsored by European Economic Community
} 
they come from $\mathrm{Pr}^{\text {3t }}$ ions in same microcrystals and same sites. Some assumption is done for the two lower lines. It is concluded that two principal types grow in fluorozirconate glasses. The ${ }^{1} \mathrm{D}_{2} \rightarrow{ }^{3} \mathrm{H}_{4}$ emission from non heated sample is the envelope of the

Figure $1-{ }^{2} \mathrm{D}_{2} \rightarrow{ }^{3} \mathrm{H}_{4}$ fluorescence after excitation at $5827 \stackrel{\circ}{\AA}$ from ZBA.

$\mathrm{Pr}^{3+} 5 \%$ at $\mathrm{T}=4 \mathrm{~K}$. (a) non-heated glass;

(b) heated $24 \mathrm{~h}$ at $330^{\circ} \mathrm{C}$ under $10^{-3}$ torr, crystallized sample.

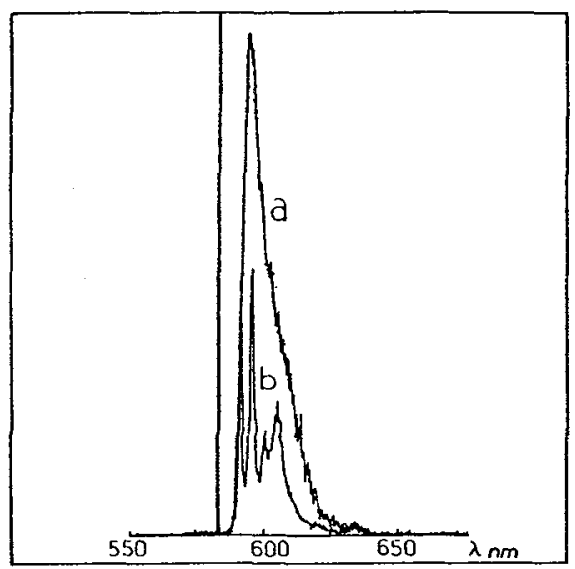

corresponding emission in crystallized samples. Consequently it is suggested that at the two types of microcrystals correspond two major types of sites for $\operatorname{Pr}^{3+}$ ions in glass. This confirms the conclusion from Eu ${ }^{3+}$ optical spectroscopy ${ }^{3}$.

Decays obey perfectly the Inokuti-Hirayama ${ }^{4}$ or rather Klafter-Blumen ${ }^{5}$ model :

$$
\Phi(t)=\exp \left[-\frac{t}{\tau_{0}}-p \Gamma\left(1-\frac{D}{s}\right)\left(\frac{t}{\tau_{0}}\right)^{D / s}\right]
$$

Cross-relaxation between excited and non excited $\mathrm{Pr}^{3+}$ ions in pairs is induced by dipole-dipole interaction $(s=6)$. For non heated samples the dimensionality $D$ is found equal to 3 and $\mathrm{p}$ is proportional to the $\mathrm{Pr}^{3+}$ concentration, as expected.

After heat-treatments at the temperature $\mathrm{T}_{g}$ of glass transition, $D$ was found smaller ( $\sim 2.75$ ) (Fig. 2). The change of dimensionality is explained by a spinodal demixtion of the glass constituents. The structure of one constituent in the other would be fractal, this fractal structure would be reflected on the $\mathrm{Pr}^{3+}$ ion distribution and on the ${ }^{1} \mathrm{D}_{2} \rightarrow{ }^{3} \mathrm{H}_{4}$ fluorescence decay.

This demixtion without crystallization was confirmed by the elastic light scattering. Furthermore it appeared that demixtion is prior to crystallization. Consequently nucleation and very small microcrystals ( $<500 \AA$ ), were not observed. And it was impossible to obtain transparent vitroceramics. 

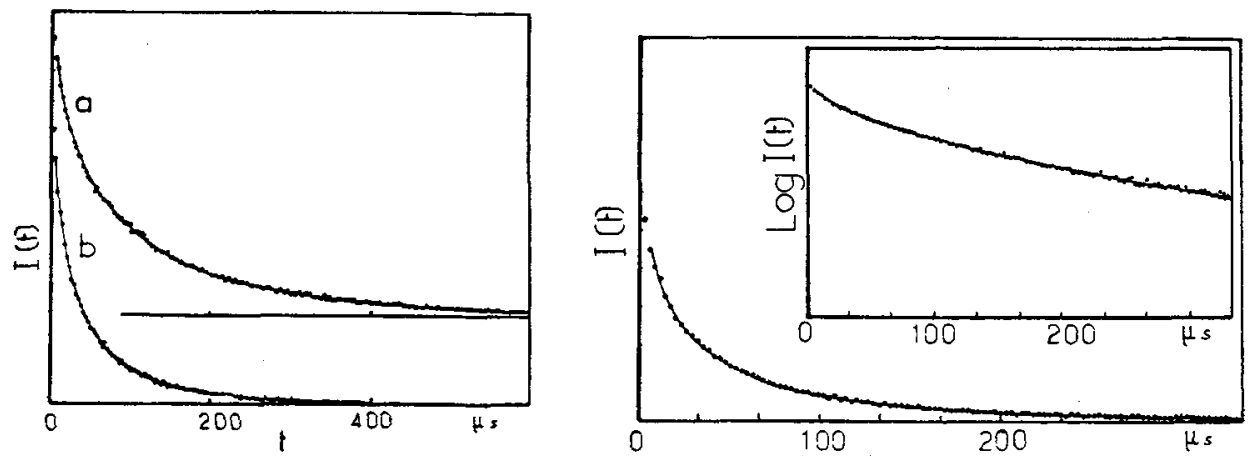

Figure 2 - Decays at room temperature of the ${ }^{1} \mathrm{D}_{2} \rightarrow{ }^{3} \mathrm{H}_{4}$ fluorescence from non-heated ZBA glasses fitted by the Inokuti-Hirayama model. (a) ZBA $0.5 \%, \mathrm{D}=3.00, \mathrm{p}=2.14$; (b) ZBA $1 \%$ $\mathrm{D}=3.00, \mathrm{p}=4.14$.

\section{CONCLUSTON}

The initial aim of this work was to observe small microcrystals in fluorozirconate glasses, and to obtain transparent vitroceramics for laser application. The demixtion prior to crystallization makes impossible to obtain such transparent laser vitroceramics from fluorozirconate glasses.

\section{REFERENCES}

1. M. Eyal, E. Greenbery, R. Reisfeld and N. Spector, Chem. Phys. Lett. 177, 108 (1985).

2. J.L. Adam and W.A. Sibley, J. Non Cryst. Solids 76, 267 (1985).

3. J.I. Adam, V. Ponçon, J. Lucas and G. Boulon, J. Non Cryst. Solids 91, 191 (1987).

4. M. Inokuti and F. Hirayama, J. Chem. Phys. 43, 1978 (1965).

5. J. Klafter and A. Blumen, J. Chem. Phys. 80, 875 (1984). 